\title{
DETERMINANTS OF INDONESIA'S DEFENSE TECHNOLOGY COOPERATION WITH TURKEY: A DECISION MAKING PERSPECTIVE
}

Cite as

Luerdi, L. \& Marisa, H. (2020). Determinants of Indonesia's Defense Technology Cooperation with Turkey: A Decision Making Perspective. Proceedings of the Second International Conference on Social, Economy, Education and Humanity - ICOSEEH, 440-445.

https://doi.org/10.5220/0009370304400445

Details

Authors: Luerdi and Hizra Marisa

Publication date: October 30, 2020

DOI: $10.5220 / 0009370304400445$

ISBN: 978-989-758-464-0

Published in: Proceedings of the Second International Conference on Social, Economy, Education and Humanity - ICOSEEH, SCITEPRESS - Science and Technology Publications, Lda, pp. 440-445 (978-989-758-464-0).

Meeting: The Second International Conference on Social, Economy, Education and Humanity (ICOSEEH), Pekanbaru, 5-7 September 2019 


\title{
Determinants of Indonesia's Defense Technology Cooperation with Turkey: A Decision Making Perspective
}

\author{
Luerdi and Hizra Marisa \\ Department of International Relations, Universitas Abdurrab, Jl. Riau Ujung No.73, Pekanbaru, Indonesia
}

Keywords: Cooperation, Defense Technology, Domestic Politics, Military and Economic Capability, International Context.

Abstract: This paper aims to describe a number of determinants of Indonesia's technology cooperation policy with Turkey. That dominant literature on Indonesia's defense relations with its traditional partners either in East Asia or in Asia Pacific while less scholars' attention to such relation beyond the regions seems to exist is a gap the paper intends to fill. The research found that Indonesia's defense ministry's role as well as political support from political parties at the parliament, state economic-military gap and the trend of emerging powers' defense self-sufficiency and self-reliance along with increased global arm trades were the significant factors which encouraged the state to agree on the cooperation ranging from joint development, production to potential sale of armaments. The research applied the decision making theory developed by William D. Coplin providing such determinants as domestic politics, state economic and military capability and international context. In addition, the research made use of the qualitative approach with a descriptive analysis. The paper argues that Indonesia has been pursuing its defense technology independence within last decade; therefore, it diversifies its defense relation beyond its traditional partners.

\section{INTRODUCTION}

The paper seeks to describe the determinants encouraging Indonesia to carry out the defense technology cooperation with Turkey whose issue belongs to international cooperation and defense studies. Defense technology development, which is overwhelmingly associated with defense industry, is such a strategic agenda the states have taken into account including Indonesia that they will step up their domestic defense industry to meet, at least, a national deterrence function against any threat.

The Indonesian government has knowingly dealt on a number of defense frameworks through defense diplomacy with ten main partners namely the United States, Australia, Malaysia, Russia, China, France, Singapore, Netherland, India and South Korea, Syafwi as cited in (Laksmana, 2012). In addition to national deterrence capability, through which, the state contributes to regional stability and security. While the cooperation has taken shape in commonly various military deals, for instance, joint military exercises, intelligent exchanges, joint patrols around border areas and arms transfers, the meaningful defense technology development deal is a relatively new sort of policy taken by the Indonesian decision makers only after 2012. The latter is based on a national constitutional mandate that the state is seriously aware with transfer technology instead of being an armaments importer state.

A mutually advantageous scheme is the characteristic of Indonesia's defense industry development to speed up the increase of defense technology acquisition as well as to control growing cost as the regards national interest (Pertahanan, 2015). The scheme is mainly aimed at reducing Indonesia's reliance on foreign military hardware supplies and is believed to be a pathway towards national defense system selfsufficiency. Such goals match the principle of Indonesia's defense industry independence in order to obtain strong, self-sufficient and competitive defense industry (Kemhan., 2018).

Indonesia and Turkey share characteristics as important regional actors affecting their region dynamics respectively. As a middle power which has long contributed to stability and security in Asia Pacific, Indonesia's defense modernization and independence are required to maintain strategic autonomy in pursuing regional diplomatic agendas (Gindarsah and Priamarizki, 2015). On the other hand, in a addi- 
tion to being a member of North Atlantic Organization Treaty (NATO), Turkey is a new emerging power gaining a reputation in pursuing its self-sufficiency and self-reliance of domestic defense technology (MacGillivray, 2019) and building defense industry competitiveness with other states (BILGEN, 2010); therefore, it is able to encounter threats targeting its domestic and regional stability without or by little relying on foreign military hardware (Bağcı and Kurç, 2017).

The defense technology cooperation started off with Indonesia's President Susilo Bambang Yudhoyono's official visit to Turkey and the signing of memorandum of understanding (MOU) in June 2010 which was ratified four years later and formally codified in the 2014 Republic of Indonesia's Law Number 19 on the Ratification of Defense Industry Cooperation between the Republic Indonesia and the Republic of Turkey.

Both sides agreed on defense technology development overseeing joint research, production, modernization and potential sales, in addition to mutual interests, security and integrity commitment explicitly stated in the law. Upon the parliament's approval, the Indonesian government was capable of commencing the concrete cooperation with Turkish government. Regarding technical and operational matters, both governments along with their respective ministries of defense and domestic defence firms talked over a number of deals which were becoming more intense shortly after Indonesia's President Joko Widodo's visit to Turkey in 2017. The cooperation covered a range of areas such as Kaplan medium tanks, MALE unmanned aerial vehicles, military communication equipment and 214-type submarines.

\section{THEORETICAL FRAMEWORK}

The research applied the foreign policy decision making theory in order to provide a description of driving factors with which Indonesia considered its defense technology cooperation with Turkey. The theoretical approach adheres to a basic assumption that any international action is defined in term of a series of decisions taken by domestic political units and state leaders either individuals or groups acting as main actors in a policy making process (Jensen, 1987). The approach reveals a black box in which a state decision making is processed and afterwards transformed into a state behavior or action.

(Coplin and Marbun, 1992) suggests some important determinants which enable to explain why a state would prefer any foreign policy such as domestic politics, economic and military capability and international context. The domestic politics, which refers to domestic political actors also called policy influencers, is such a fundamental factor which influences the state decision making. The policy influencers are divided into four types:

- Bureaucratic influencers; individuals or institutions in a state executive body who assist the decision makers in formulating and executing a state policy;

- Partisan influencers; political parties within a state legislature whose roles vary like bridging the gap between public demands and executive policies, either supporting and blocking a government's policy;

- Interest influencers, informal groups or organizations which represent particular interests and struggle to influence a government to either impose or deny any policy in accordance with their preferences; and

- Mass influencers, public opinions generated by particular population and frequently considered by the state decision makers while formulating a foreign policy (Coplin and Marbun, 1992).

The state decision makers need to balance their commitment to the state capability by considering constraints driven by both economic and military situation (Coplin and Marbun, 1992). Both economy and military, which have long been material powers and mutually affected, are often associated to the state geographical elements from which it has a capability of defending its security against potential threats coming from both outside and within. While domestic developments do matter in the state foreign policy making, the international environment, so-called international context, complements during the process. The international context is a product of the past, present and future behaviors preferred by all states which would be anticipated by the state decision makers (Coplin and Marbun, 1992).

The foreign policy decision makers are those who encounter a particular situation and they have to consider all determinants like domestic politics, economic and military capability and international context (Coplin and Marbun, 1992). Decision making is basically such a rational problem solving that the decision makers consider a number of existing alternatives of options as well as of goals, and one of which is taken as the best decision (Coplin and Marbun, 1992). On the other hand, a foreign policy action is the implementation of preferred option taken by the state decision makers. During the decision making process, 
national interests remain the utmost of foreign policy goals which are actually the policy influencers' representation.

The paper argues that Indonesia's defense ministry and political parties were the bureaucratic and partisan influencer respectively whose roles influenced the decision making of such strategic policy. Such domestic determinants were bolded by Indonesia's economic-military gap along with international environment; emerging powers' ambition for defense technology self-reliance and the rise of global arms transfers. The Committee for Defense Industry Policy (KKIP, Komite Kebijakan Industri Pertahanan) was responsible for all strategic decision making regarding the national defense technology including foreign cooperation. As the state legitimate institution, the committee viewed the all determinants serving national interests namely defense and economy. The technical know-how or technology transfer from Turkey was the main goal of cooperation and with which the state would maintain a maximum deterrence capability against threats, boost domestic defense industry to reach military hardware independence and take advantage of economic profits through arms exports. Therefore, the cooperation scheme sought joint productions as well as potential joint sales, instead of sole armaments purchases.

\section{METHODS}

The research applied the qualitative approach with a descriptive analysis which only focused on the explanative unit; the factors (determinants) encouraging Indonesia to conduct the defense technology cooperation with Turkey. Due to a library research, it employed both online and offline resources ranging from books, scientific journals, reports and other relevant documents. The data were analysed through an analytical inductive technique with which the universal explanation on particular phenomenon was searched, comprising some stages:

- Defined a rough research question;

- Determined hypothetical explanation of the question;

- Collected data and checked cases;

- Confirmed the hypothesis provided that deviant cases were not found;

- However, in case of deviance, either the hypothesis ought to be reformulated and more data ought to be collected to check the cases, or the hypothetical explanation ought to be redefined in order to remove the deviant cases (Bryman and Burgess, 2002).

The technique emphasized the importance on confirming, reshaping hypothesis, and redefining hypothetical explanation during data collection process and cases evaluation. Despite a confirmation of the cases during the research, collecting data remained necessary in order to result in a strong hypothetical explanation. The research eventually embraced the hypothetical explanation 'that Indonesia conducted the defense technology cooperation with Turkey was encouraged by both domestic and international environment all of which were processed in a decision making system.'

\section{RESULTS AND DISCUSSION}

Based on the theoretical explanation previously elaborated, the cooperation between Indonesia and Turkey was encouraged by a number of factors such as Indonesia's defense ministry's role and the parties' political support at the parliament, the gap between economic and military capability and the trend of emerging powers' preference for defense technology selfsufficiency and self-reliance along with the rising global arms transfers.

\subsection{Defense Ministry's Role and Political Parties' Support}

The KKIP is a committee representing Indonesia's government in coordinating national policies, which is responsible for planning, formulating, controlling, synchronizing and evaluating defense industry to meet self-sufficient military hardware (Kemhan., 2018; KKIP, 2018). As a coordinator, the committee is mandated to coordinate the execution and control of national policies on defense industry including cooperation with foreign states with the aim of advancing and promoting Indonesia's defense industry (Kemhan., 2018; KKIP, 2018).

The Indonesia's defense ministry was viewed the most influential actor in the committee acting as a second chair whose position was only right below the president, while other state ministries were subordinated within its coordination. Such position helped transfer its function such as planning, determining and executing defense policies (Kemhan., 2018). In the decision making process regarding the cooperation with Turkey, the ministry practically ensured that the two states' relation contributed to domestic arms availability and national defense technology 
self-reliance in accordance with the defense ministry and KKIP's shared vision. It was demonstrated that the ministry's role molded the cooperation through several official visits and talks about a variety of plans and project agreements with its Turkey's defense ministry counterpart.

So did the political parties making up the parliament particularly the Commission I (Komisi I DPR $\mathrm{RI}$ ) as the Indonesian government's partner in foreign relation matters pay support for the cooperation. After the MOU signatory, the commission delegates conducted visit to Turkey and carried out a meeting with Turkish stakeholders in order to gather information in addition to watching Turkish domestic defense industry development. The activities were initiated to ease deliberations on a constitutional draft on the two states' cooperation among the parties' fractions (Fallis, 2013).

Now that all fractions of the Commission I could agree on the cooperation draft by considering the goal of national defense technology capacity, the deliberation was brought to the parliament plenary session. Looking on the 2012 Indonesia's Law Number 16 on the defence industry prioritizing the empowerment of domestic armaments and defense technology independence, all political parties' representatives approved the cooperation draft to be the 2014 Indonesia's Law Number 19. Such ratification was a form of the political support coming from political parties at the Indonesia's legislature so that the Indonesian government had a legal mandate executing the cooperation which was one of the national strategic policies.

\subsection{Economic-Military Gap}

Indonesia is such a huge archipelagic state that it shall require a sufficient economic and military capability to guarantee its sovereignty. However, the relation of economic and military capability, on the other hand, created a vulnerability in maintaining a maximum state defense function.

The Coordinating Minister for Political, Legal and Security Affairs, L.B. Panjaitan (2016) once stated that in spite of an annually rising trend, the amount of military budget had never exceeded one percent of the national GDP (the average was only 0.78 and 0.82 percent from a period of 2000 to 2004 and 2005 to 2014 respectively). Realizing the military budget as much as 1.5 percent of the GDP as expected by many Indonesian leaders seemed long way to go as the amount would risk other public sectors. (Panjai$\tan , 2016)$.

Not only did the low ratio to GDP show, the military expenditure composition was becoming a consid- eration for decision makers. The military expenditure had to be allocated not only for capital but also for personnel and goods. In fact, the combined personnel and goods expenditure dominated the whole expenditure compared to capital expenditure ideally used for upgrading the military hardware. That the capital expenditure only reached IDR 12.8 trillion (2010), 17.7 trillion (2011), 27.9 trillion (2012), 42.2 trillion (2013) and 30.4 trillion (2014) was by far lower than the others if combined (Panjaitan, 2016). The insufficient budget for capital expenditure markedly slowed up the state capability of meeting its minimum essential force (MEF) previously designed to build a deterrence strategy.

The situation was worsened by the state dependence on arms supplies from the main defense partners which absolutely cost its foreign policy and sovereignty against foreign interventions when it came to domestic problems. The arms embargo which the United States once imposed and Australia's interventionist foreign policy in East Timor separatism were fresh experiences for Indonesia (Laksmana, 2012). The other consequence of such dependence was that Indonesia had 173 variants of defense system transferred from 17 main supplier states which caused both complexity of inter-operation readiness and rising maintenance cost of worn out military hardware (Sebastian and Gindarsah, 2013; Gindarsah and Priamarizki, 2015). The situation was complicated with less competitive domestic defense industry because of low human resources along with less research and development programs related to defense technology (Tippe, 2018).

Having realized the economic-military gap, the state decision makers viewed that reducing dependence on major powers by improving on domestic production capability was a strategic policy rather than importing the ready-used arms. The cooperation in producing defense armaments with Turkey could be one of the solutions to help meet some of Indonesia's domestic defense system. The two states could share costs in producing medium tanks, drones, submarines and other military hardware. More importantly, Indonesia received the defense technology transfer through the cooperation which envisioned the future national defense technology independence. 


\subsection{Self-sufficiency and Self-reliance Preference among Emerging Powers and Increased Global Arms Transfer}

Indonesia was aware of that the emerging powers had been pursuing their defense technology independence through their domestic defense industry empowerment. The globalization of arms transfers post Cold War provided opportunities for the states to meet their military armaments either alone or through cooperation with others which had more advanced defense technology taking shape in many kinds such as joint developments and productions, partnerships, mergers and acquisitions and joint ventures (Kurç and Bitzinger, 2018). Not only could such interaction keep a tight lid on cost among the states, it created rising arms trades in line with the export-oriented goal of their defense industry. (Institute., 2019) reported that there existed the global arms transfers not only engaging major but also a number of middle powers.

As a middle as well as a regional power, Indonesia perceived an opportunity to narrow the existing domestic defence weaknesses ranging from less developed defense technology acquisition, insufficient strategic military hardware to dependence on major powers' supplies. In addition, Indonesia looked on its future armaments exports as a consequence of defense globalization which it would possibly gained thanking to the defense technology cooperation. Turkey was viewed as a state with a respectable reputation for its domestic defense technology development and aggressive efforts to expand markets for its defense industry products. During a period of 2013-2017, Turkey ranked the 15th among top 25 global arms exporters (Institute., 2019). With the collaboration, Indonesia expected to meet some of its strategic arms need, boost its domestic defense industry through technology transfer and vary the market for its defense industry.

\section{CONCLUSION}

The interaction between domestic and international factors encouraged Indonesia to carry out the cooperation in defense technology with Turkey. For the state foreign policy decision makers, interpreting the situation and alternative options became a need to bring about a strategic policy as an effort to pursuit national interests. The defense technology cooperation between Indonesia and Turkey was influenced by Indonesian defense ministry and political supports among political parties at the legislature, strengthened by the existing economic-military gap and the emerging powers' preference for defense technology self-sufficiency and self-reliance along with the rising global arms trades.

In Indonesia's point of view, the two states' cooperation would enable to step up its domestic defense industry capacity inasmuch as with which technology transfer entailed. The domestic defense technology development would benefit Indonesia in maintaining its territorial integrity and sovereignty through deterrence capability betterment, upholding its foreign policy independence to contribute to the regional stability and shifting to be a significant player in global armaments transfers in the future.

Turkey was one of the chosen partner states in realizing such agenda since Indonesia dealt on similar cooperation in Asia and other regions. The strategic decision within the cooperation with Turkey was limited to development and production of mediumtanks, military communication tools, drones and submarines, some of which are still ongoing. After all, the cooperation policy indicates that Indonesia has begun diversifying its foreign policy on international defense cooperation especially in term of technology transfer, no longer by only relying on traditional partners. The two states' relation could forward to strategic bilateral partnership bearing in mind that Turkey has been extending its foreign policy global role including into Southeast Asia.

\section{REFERENCES}

Bağcı, H. and Kurç, Ç. (2017). Turkey's strategic choice: buy or make weapons? Defence Studies, 17(1):38-62.

BILGEN, H. (2010). Competitiveness of defense industry in turkey. International Journal of Economics and Finance Studies, 2(1):63-70.

Bryman, A. and Burgess, R. G. (2002). Developments in qualitative data analysis: an introduction. In Analyzing qualitative data, pages 15-31. Routledge.

Coplin, W. D. and Marbun, M. (1992). Pengantar politik internasional: Suatu telaah teoritis. Bandung: Sinar Baru.

Fallis, A. (2013). Kunjungan Kerja Komisi I DPR RI Ke Turki. Journal of Chemical Information and Modeling, 53(9):1689-1699.

Gindarsah, I. and Priamarizki, A. (2015). Politics, security and defense in indonesia: The pursuit of strategic autonomy. In Indonesia's Ascent, pages 130-154. Springer.

Institute., S. I. P. R. (2019). (2018) Trends in International Arms Transfers. SIPRI Fact Sheet.

Jensen, L. (1987). Explaining Foreign Policy. The USA: Prentice Hall, Inc. 
Kemhan. (2018). Tugas dan Fungsi [Duties and Functions]. [Online] Available from: https://www.kemhan.go.id/tugas-dan-fungsi [Accessed 5th.

KKIP (2018). KKIP - Komite Kebijakan Industri Pertahanan Indonesia.

Kurç, Ç. and Bitzinger, R. A. (2018). Defense industries in the 21st century: A comparative analysis-the second e-workshop.

Laksmana, E. A. (2012). Regional order by other means? examining the rise of defense diplomacy in southeast asia. Asian Security, 8(3):251-270.

MacGillivray, I. (2019). Turkey's Defense Industry: A Burgeoning, Global Business Reports: Turkey Aerospace and Defense. [Online] Available from: https://www.gbreports.com/publication/turkeyaerospace-2016 [Accessed 4th.

Panjaitan, L. (2016). Menciptakan stabilitas melalui peningkatan pertahanan dan pemerataan ekonomi. In Seminar Universitas Indonesia, volume 20.

Pertahanan, K. (2015). Buku Putih Pertahanan Indonesia 2015.

Sebastian, L. C. and Gindarsah, I. (2013). Assessing military reform in indonesia. Defense \& Security Analysis, 29(4):293-307.

Tippe, S. (2018). Defense offset policy in indonesia. International Journal of Administrative Science and Organization. [Online], 20(2):85-89. 